\title{
Physico-chemical and microbiological evaluation of açaí pulp processed in Igarapé-Miri, PA
}

Avaliação físico-química e microbiológica dos padrões de qualidade e identidade da polpa de açaí processada em Igarapé-Miri, PA

\author{
C. B. Aires ${ }^{1 *}$; P. W. P. Gomes ${ }^{2}$; A. C. A. Pelais ${ }^{3}$; E. L. Figueiredo ${ }^{3}$; L. H. da S. \\ Martins $^{4}$ \\ ${ }^{1}$ Department of the Center for Natural Sciences and Technology of State University of Pará, 68400000, Cametá-PA, \\ Brazil \\ ${ }^{2}$ Graduate Program in Chemistry of the Federal University of Pará, 66075-970, Belém-PA, Brazil \\ ${ }^{3}$ Department of Food Technology of State University of Pará, 66095100, Belém-PA, Brazil \\ ${ }^{4}$ Institute of Animal Health and Production of Federal Rural University of Amazon, 66077830, Belém-PA, Brazil
}

*cassiab.aires@hotmail.com

(Recebido em 11 de junho de 2020; aceito em 02 de setembro de 2020)

\begin{abstract}
Açaí is a fruit widely consumed in northern Brazil; has a high energy and antioxidant value. In addition, it is rich in anthocyanins, lipids, carbohydrates, fibers, vitamins and minerals. However, inadequate practices lead to physical, chemical and biological contamination during production, processing and transportation, consequently increasing the risk of diseases transmitted by this food. In this work, we evaluated the physicalchemical quality ( $\mathrm{pH}$ and anthocyanins), microbiological (thermotolerant coliforms, mesophilic aerial bacteria, filamentous fungi and yeasts, Salmonella ssp; Trypanosoma cruzi) and heavy metals from açaí pulp from an industry located in Igarapé-Miri-PA. The pH results ranged from 5.10 to 5.35, anthocyanins between $67 \mathrm{mg} / 100 \mathrm{~g}$ to $113 \mathrm{mg} / 100 \mathrm{~g}$, both were in accordance with current Brazilian legislation. As for the microbiological results, contamination by Salmonella ssp. and Trypanosoma cruzi; for heavy metal analysis the samples were in accordance with current legislation. Therefore, we suggest that the pulps produced in Igarapé-Miri have a quality standard to reach the consumer market without risks to human health.

Keywords: quality control, legislation, Microbiology.

O açaí é um fruto muito consumido na região norte do Brasil; apresenta elevado valor energético e antioxidante. Além disso, é rico em antocianinas, lipídeos, carboidratos, fibras, vitaminas e minerais. No entanto, práticas inadequadas levam a contaminações físicas, químicas e biológicas durante a produção, processamento e transporte; consequentemente aumenta-se o risco de doenças transmitidas por este alimento. Neste trabalho, avaliamos a qualidade físico-química (pH e antocianinas), microbiológica (coliformes termotolerantes, bactérias aéreas mesófilas, fungos filamentosos e leveduras, Salmonella ssp; Trypanossoma cruzi) e metais pesados em polpas de açaí de uma indústria localizada em Igarapé-Miri-PA. Os resultados de $\mathrm{pH}$ variaram entre 5,10 e 5,35, antocianinas entre $67 \mathrm{mg} / 100 \mathrm{~g}$ e $113 \mathrm{mg} / 100 \mathrm{~g}$; ambos estavam de acordo com a legislação brasileira vigente. Quanto aos resultados microbiológicos, não se identificou contaminação por Salmonella ssp. e Trypanossoma cruzi; para as análises de metais pesados as amostras estavam de acordo com a legislação vigente. Portanto sugerimos que as polpas produzidas em Igarapé-Miri possuem padrão de qualidade para chegar até o mercado consumidor sem riscos à saúde.
\end{abstract}

Palavras-chave: controle de qualidade, legislação, Microbiologia.

\section{INTRODUCTION}

The growing concern with the topic of food quality has increased in recent years; therefore, consumers make greater demands. It is noted that the small to large industries, in their majority, are out of the adjustments that the legislation requires, since, many entrepreneurs still do not aim at product quality, but only profit. In addition, health agencies have many problems related to inspections, such as insufficient inspectors, structural problems, lack of investments, lack of harmonization between agencies from different spheres (Federal, State and Municipal), making 
good inspection impossible. Economic development and the needs to fit into the current market have brought changes in the food profile of industries [1]. Due to inappropriate practices, physical, chemical and biological contamination during production, processing, transportation and consumption substantially increases the risk of foodborne illnesses [2].

Quality standards in the food sector are increasingly demanding, as food industries are looking for a more productive and more reliable process for the consumer market, the consumer through visual characteristics such as taste, odor, color and even nutritional composition can observe the quality. At the same time that the industries also prioritize nutritional characteristics, such as the appropriate weight, as well as, fundamentally, their safety regarding physical, chemical and biological contaminants [3].

The açaizeiro (Euterpe oleracea Mart.) is a palm tree (fruit) typical of the Amazon region, from where the fruit (açaí) that provides the pulp be extracted [4]. Açaí has a high-energy value, is rich in antioxidants, especially anthocyanin, in addition to containing lipids, carbohydrates, fibers, vitamins and minerals such as iron [5]. The pulp is used to produce various types of drinks and food products, such as ice cream, liqueurs, sweets and jellies consumed throughout Brazil [5].

In Brazil, in 2018, 380 cases of chagas disease, caused by the transmission of the protozoan Trypanosoma cruzi, were confirmed, where the State of Pará registered the highest rate of cases, and the most frequent form of transmission continues to be orally, through the consumption of açaí and sugar cane [6]. According to data from the Health Department of the State of Pará - SESPA, until August 2019, 97 cases of Chagas disease were registered [7].

The municipality of Igarapé-Miri is known as the "World Capital of Açaí", because it is the largest producer and exporter of this fruit in the world, where it still produces and transports it to various places, supplying several tables of the paraense families, taken in most sometimes to the capital of the State of Pará and to several municipalities. Açaí and industries are important components for the municipality's economy [8].

According to data from the Secretaria of Agricultural Development and Fisheries - SEDAP [9], the municipality concentrates seven industries for the processing of açaí pulps, in which some already produce products derived from the pulps, adding value to the product.

In this context, the aim of this work was to evaluate the physical-chemical, microbiological, and content-heavy metal quality of the açaí pulp produced by an industry located in Igarapé-Miri-PA. For that was followed the quality and identity standards required by the legislation of Brazil and of the Municipality, in order to guide the company about quality standards, as well as to contribute to the development of industries in the region.

\section{MATERIAL AND METHODS}

\subsection{Collection of study samples}

The samples of processed açaí pulps were collected in an industry in the municipality of IgarapéMiri, called industry X (chosen because its good quality, reference, and it has all legal documentation in up to date), which works with the processing of açaí pulps, 35 samples of 1000 $\mathrm{g}$ were analyzed, classified as popular, medium and special açaí under freezing processing. They were packed in polyethylene pots, frozen and stored under moisture protection, in order to minimize subsequent contamination. Followed by the forwarding of the material to the Monitora laboratory - located in the city of Belém-PA to carry out the analyzes described in the next topics.

\subsection{Physicochemical analysis}

\section{$2.2 .1 \mathrm{pH}$}

The $\mathrm{pH}$ analysis was performed in triplicate, where approximately $100 \mathrm{~mL}$ of the sample was used, added in a $250 \mathrm{~mL}$ Becker, where the reading was made directly with the aid of a $\mathrm{pH}$ meter 
model AK90 (Akso, Rio Grande do Sul, Brazil) calibrating with buffer solutions pH 4.0 and 7.0 according to Adolf Lutz methods [10].

\subsubsection{Total anthocyanins (TA)}

This analysis was performed according to the methodology described by Giusti and Wrolstad (2001) [11]. For this procedure, a buffer solution of $\mathrm{pH} 1.0$ (potassium chloride/hydrochloric acid) and $\mathrm{pH} 4.5$ (sodium acetate/acetic acid) was used. After the were filtered, $1 \mathrm{~mL}$ of pure açaí sample was added in previously identified test tubes, and then in the same tubes, $9 \mathrm{~mL}$ of $\mathrm{pH} 1$ buffer solution was added the same procedure was performed for the $\mathrm{pH} 4.5$ buffer solution. The tubes were shaken manually for $15 \mathrm{~min}$. After this procedure, the samples were read on a spectrophotometer UV-Vis (Nova/1105), previously calibrated with the reaction blank, consisting of the buffer solutions themselves. Readings were conducted at $520 \mathrm{~nm}$ and $690 \mathrm{~nm}$ wavelengths, respectively. The results were expressed in $\mathrm{mg}$ of anthocyanins/L of sample, as shown in Equation 1.

Equation 1.

$$
C=[(A 520-A 690) p H 1,0-(A 520-A 690) p H 4,5] . D . F
$$

Where:

$\mathrm{C} \rightarrow$ concentration of anthocyanins in $\mathrm{mg} / \mathrm{L}$ of juice

$\mathrm{D} \rightarrow$ dilution made in the samples

$\mathrm{F} \rightarrow$ molar extinction coefficient of anthocyanins - 29600 for Cyanidin-3-glycoside (found in blackberry)

The results obtained for Total Anthocyanin (TA) were expressed in mg of anthocyanins/100g of sample.

\subsection{Microbiological analysis}

\subsubsection{Sampling and preparation}

Thirty-five samples of açaí pulp, obtained during the period from August to September 2019 (period of the açaí harvest), were transported in isothermal boxes to analysis in laboratory. From each sample, $25 \mathrm{~g}$ were aseptically removed, which were transferred to flasks containing $225 \mathrm{~mL}$ of sterile peptoned water (Kasvi, Paraná, Brazil) and after homogenization, serial dilutions were made $10^{-1}, 10^{-2}, 10^{-3}, 10^{-4}, 10^{-5}$, and $10^{-6}$, which were used in all microbiological determinations.

\subsubsection{Analysis of thermotolerant coliforms}

For the analysis of coliforms, the series of three multiple tubes was used, using the Most Probable Numbers Technique - MPN according to APHA [13], which consists of estimating the density of viable organisms present in a sample under analysis. Lauryl Sulfate Tryptose Broth (LST) - (Kasvi, Paraná, Brazil) incubated at $35^{\circ} \mathrm{C}$ for a period of 24 to 48 hours was used for the analysis.

The Confirmation of the presence of coliforms at $45^{\circ} \mathrm{C}$ was carried out by inoculating the colonies in Broth Escherichia Coli (Merck, Darmstadt, Germany). This was incubated at $45^{\circ} \mathrm{C}$ for 24 - 48 hours, in a water bath with agitation. Moreover, confirmation of the presence of coliforms at $35^{\circ} \mathrm{C}$ was carried out by inoculating the colonies in Caldo Verde Brilhante - (Merck, Darmstadt, Germany) and incubating at $35^{\circ} \mathrm{C}$ for 24 - 48 hours.

\subsubsection{Analysis of aerobic mesophilic bacteria}

The standard count analysis in mesophilic aerobic bacteria plaques was performed according to APHA [12]. $1 \mathrm{~mL}$, from $10^{-3}$ to $10^{-6}$ dilutions, was seeded and deposited on the bottom of sterile 
Petri dishes. Then, about $15 \mathrm{~mL}$ of agar for plate - (Kasvi, Paraná, Brazil) was added, melted and cooled to a temperature around $45^{\circ} \mathrm{C}$. After homogenization and solidification of the agar at room temperature, the plates were incubated at $35^{\circ} \mathrm{C}$ for 48 hours.

\subsubsection{Analysis of filamentous fungi and yeasts}

This analysis was performed through surface inoculation, according to the method of ISO 215271 [13], from $25 \mathrm{~g}$ of the sample homogenized with $225 \mathrm{~mL}$ of a saline tryptone solution - (Kasvi, Paraná, Brazil). The culture medium Agar Potato Dextrose was used and incubation at $22^{\circ} \mathrm{C}$, for 4 days.

\subsubsection{Analysis of Salmonella ssp.}

Analysis of Salmonella ssp. was carried out by inoculation in plates in Semi-Solid RappaportVassiliadis medium (Acumedia), according to the method of ISO 6579 [14] for qualitative determination, using the Presence/ Absence technique.

\subsubsection{Análise de Tripanossoma cruzi}

The T. cruzi analysis was performed according to the PCR-ISO 20837 methodology [15].

\subsection{Heavy metals analysis}

Electrochemical Atomic Absorption Spectrometry EPA 7000B performed the analysis of Total Antimony and Total Cadmium according to the determination of Metals [16]. The analysis of total arsenic was performed according to the SM 3111 methodology [17]. For the analysis of total lead and total copper, the USEPA 6010C methodology [18] was adopted, this method is based on the determination of trace elements in aqueous solution, properly acidified and/or digested in microwaves. For mercury, the determination was according to the USEPA 1631 method [19].

\subsection{Statistical analysis}

The results of the physical-chemical analyzes of the açaí pulps were subjected to analysis of variance (ANOVA) and the calculations of the averages by the Tukey test at 5\% probability with the aid of the Past 4.0.2 statistical software [20].

Principal Component Analysis (PCA) and Hierarchical Cluster Analysis (HCA) were used, with the help of the free version of the Past 4.0.2 software [20]. For analysis of hierarchical clusters and main components, 35 samples were evaluated in response to the experimental design in terms of components. The application of the multivariate study provided a clear and objective explanation of the correlation and variance of the samples when submitted to the grouping of individuals with similar characteristics.

\section{RESULTS AND DISCUSSION}

\subsection{Physicochemical analysis}

Ordinance No. 94 of August 30, 2016 [21] classifies açaí in three ways: popular, medium and special açaí. The first, popular or fine açaí, is defined by its pulp being extracted with the addition of water and filtration, presenting 8 to $11 \%$ of total solids and a light dense appearance. The second, medium or regular, is defined by its pulp being extracted with the addition of water and filtration, presenting over 11 to $14 \%$ of total solids and a dense appearance. The third, special or thick, is 
defined by its pulp being extracted with the addition of water and filtration, presenting above $14 \%$ of total solids and a very dense appearance.

Table 1 shows the results of the physical-chemical analyzes of frozen açaí pulps. The $\mathrm{pH}$ results of açaí samples, which ranged from 5.10 to 5.35, show that these results fit with what is allowed, as they fall within the standards established by the normative instruction of No. 37, from 01 October 2018 [22] ranging from 4 to $6.2 \mathrm{pH}$. Comparing to the study by Aquino et al. (2014) [23], where they studied the physical-chemical and microbiological evaluation of açaí (Euterpe oleracea), similar results of $\mathrm{pH}$ were found, values ranging from $4.27 \pm 0.73$ to $5.73 \pm 0.01$.

Table 1: Physico-chemical characterization of açaí pulps in Igarapé-Miri, Pará.

\begin{tabular}{|c|c|c|c|}
\hline \multicolumn{4}{|c|}{$\begin{array}{c}\text { Physical-chemical analysis } \\
\text { Average } \pm \text { SD* }\end{array}$} \\
\hline Type of açaí & Batch & pH & $\begin{array}{c}\text { Anthocyanins } \\
\text { mg/100g }\end{array}$ \\
\hline \multirow{8}{*}{ Popular Açaí } & 1 & $5.21 \pm 0.02^{\mathrm{a}}$ & $77.0 \pm 0.03^{\mathrm{a}}$ \\
\hline & 2 & $5.30 \pm 0.04^{b}$ & $98.0 \pm 0.02^{\mathrm{b}}$ \\
\hline & 3 & $5.24 \pm 0.01^{\mathrm{a}}$ & $102 \pm 0.05^{\mathrm{c}}$ \\
\hline & 4 & $5.23 \pm 0.01^{\mathrm{a}}$ & $100 \pm 0.04^{c}$ \\
\hline & 5 & $5.21 \pm 0.05^{\mathrm{a}}$ & $92.0 \pm 0.00^{\mathrm{d}}$ \\
\hline & 6 & $5.28 \pm 0.03^{\mathrm{a}}$ & $94.0 \pm 0.01^{\mathrm{d}}$ \\
\hline & 7 & $5.15 \pm 0.01^{\mathrm{a}}$ & $101 \pm 0.04^{\mathrm{a}}$ \\
\hline & 8 & $5.10 \pm 0.02^{\mathrm{c}}$ & $89.0 \pm 0.07^{\mathrm{e}}$ \\
\hline \multirow{24}{*}{ Medium Açaí } & 1 & $5.21 \pm 0.03^{\mathrm{a}}$ & $77.0 \pm 0.10^{\mathrm{a}}$ \\
\hline & 2 & $5.20 \pm 0.04^{\mathrm{a}}$ & $85.0 \pm 0.09^{\mathrm{e}}$ \\
\hline & 3 & $5.35 \pm 0.05^{\mathrm{b}}$ & $113 \pm 0.05^{\mathrm{f}}$ \\
\hline & 4 & $5.26 \pm 0.06^{\mathrm{a}}$ & $85.0 \pm 0.03^{\mathrm{e}}$ \\
\hline & 5 & $5.21 \pm 0.03^{\mathrm{a}}$ & $93.0 \pm 0.04^{\mathrm{d}}$ \\
\hline & 6 & $5.27 \pm 0.04^{\mathrm{a}}$ & $89.0 \pm 0.05^{\mathrm{e}}$ \\
\hline & 7 & $5.26 \pm 0.02^{\mathrm{a}}$ & $108 \pm 0.02^{\mathrm{g}}$ \\
\hline & 8 & $5.23 \pm 0.05^{\mathrm{a}}$ & $95.0 \pm 0.01^{\mathrm{d}}$ \\
\hline & 9 & $5.20 \pm 0.06^{\mathrm{a}}$ & $78.0 \pm 0.40^{\mathrm{a}}$ \\
\hline & 10 & $5.21 \pm 0.02^{\mathrm{a}}$ & $81.0 \pm 0.04^{b}$ \\
\hline & 11 & $5.17 \pm 0.02^{\mathrm{b}}$ & $76.0 \pm 0.03^{\mathrm{a}}$ \\
\hline & 12 & $5.15 \pm 0.01^{b}$ & $98.0 \pm 0.04^{\mathrm{c}}$ \\
\hline & 13 & $5.23 \pm 0.04^{\mathrm{a}}$ & $99.0 \pm 0.00^{c}$ \\
\hline & 14 & $5.21 \pm 0.03^{\mathrm{a}}$ & $87.0 \pm 0.07^{\mathrm{d}}$ \\
\hline & 15 & $5.28 \pm 0.03^{c}$ & $67.0 \pm 0.02^{\mathrm{e}}$ \\
\hline & 16 & $5.20 \pm 0.01^{\mathrm{a}}$ & $79.0 \pm 0.03^{\mathrm{a}}$ \\
\hline & 17 & $5.19 \pm 0.01^{b}$ & $88.0 \pm 0.04^{c}$ \\
\hline & 18 & $5.24 \pm 0.05^{\mathrm{a}}$ & $89.0 \pm 0.05^{\mathrm{c}}$ \\
\hline & 19 & $5.30 \pm 0.06^{c}$ & $83.0 \pm 0.06^{\mathrm{b}}$ \\
\hline & 20 & $5.18 \pm 0.05^{b}$ & $101 \pm 0.07^{\mathrm{f}}$ \\
\hline & 21 & $5.29 \pm 0.05^{\mathrm{c}}$ & $103 \pm 0.08^{\mathrm{f}}$ \\
\hline & 22 & $5.24 \pm 0.04^{\mathrm{a}}$ & $92.0 \pm 0.03^{\mathrm{d}}$ \\
\hline & 23 & $5.26 \pm 0.03^{\mathrm{a}}$ & $89.0 \pm 0.02^{\mathrm{d}}$ \\
\hline & 24 & $5.16 \pm 0.03^{b}$ & $94.0 \pm 0.03^{\mathrm{d}}$ \\
\hline \multirow{3}{*}{ Special Açaí } & 1 & $5.27 \pm 0.01^{b}$ & $88.0 \pm 0.08^{b}$ \\
\hline & 2 & $5.33 \pm 0.06^{a}$ & $94.0 \pm 0.07^{a}$ \\
\hline & 3 & $5.33 \pm 0.01^{a}$ & $95.0 \pm 0.02^{a}$ \\
\hline Standard** & Min. Max. & $4.0-6.2$ & 0.44 \\
\hline
\end{tabular}

*Average and standard deviation of 35 açaí samples. ** Standard established by the Normative Instruction of No. 37, of October 1, 2018. Ministry of Agriculture, Livestock and Supply. Means with equal letters in the same column indicate that there is no significant difference by the Tukey test at $95 \%$ confidence. 
In our study, the results were higher than values found by Almico et al. (2018) [24], these authors found value of $\mathrm{pH}$ ranged $4.29 \pm 0.15$ to $4.12 \pm 0.35$. The $\mathrm{pH}$ of food is a determining factor in the multiplication of microorganisms - most of the deteriorants multiply optimally at $\mathrm{pH}$ close to neutrality (6.6 to 7.5$)$ [25].

Thus the favorable $\mathrm{pH}$ mainly affects the respiration of microorganisms, by the action of enzymes and the transport of nutrients from the inside of the microbial cell preventing the multiplication of deteriorating and pathogenic microorganisms, however when the $\mathrm{pH}$ is unfavorable, it causes an increase in the lag phase of microbial multiplication, compromising the quality of the food [26].

The values of anthocyanin in this work ranged between $67 \mathrm{mg} / 100 \mathrm{~g}$ to $113 \mathrm{mg} / 100 \mathrm{~g}$, being higher than what is allowed by the legislation, since the minimum established is $0.44 \mathrm{mg} / 100 \mathrm{~g}$, according to normative instruction No. 37 [23]. Rogez et al. (2011) [27] studied the content of anthocyanins in açai pulps and found results ranging from $109 \mathrm{mg} / 100 \mathrm{~g}$ to $165 \mathrm{mg} / 100 \mathrm{~g}$ values close to the study. Da Silva et al. (2017) [28] studied the assessment of nutritional composition and capacity antioxidant of bioactive compounds from açaí pulp and found results of total anthocyanins in açaí pulps similar to the present study, which was $73.54 \mathrm{mg} / 100 \mathrm{~g}$. Anthocyanin are extremely unstable compounds, sensitive to heat, light, oxygen and enzymatic action [29]. Thus, the variability of the observed results may be related to the time and type of processing of the pulp, the type of packaging and packaging time, methods extraction for analysis, among other factors [28].

\subsection{Microbiological analysis}

Table 2 shows the results of the microbiological evaluation of frozen açai pulps of the popular, medium and special açai type (aerobic mesophilic bacteria, thermotolerant coliforms, filamentous fungi and yeasts, Salmonella ssp. and Trypanosoma cruzi.).

Normative Instruction No. 37 of October 1, 2018 [22] states that Trypanosoma cruzi should not be detectable in $25 \mathrm{~g}$ of the sample. The results showed that the samples did not show contamination by Trypanosoma cruzi in $25 \mathrm{~g}$ of sample. De Mattos et al. (2019) [30] studied the determination of the viability of Trypanosoma cruzi in açaí pulp and had similar results with this work. A study by Passos et al. (2012) [31] where they studied the survival of Trypanosoma cruzi in açaí pulp: an in vitro and in vivi study, found positive results for Trypanossoma cruzi in açai pulp. It is noteworthy that this parasite is responsible for the transmission of Chagas disease, being a danger for those who consume contaminated food. Therefore, infection of plant-based foods in natura by Trypanosoma cruzi is accidental and can occur during harvest, storage, transport or even during the preparation stage [32].

Therefore, it is necessary to take great care in Good Agricultural Practices during all stages, from harvest to consumption, another important step that contributed to the non-detection of Trypanosoma cruzi in the samples was the performance of bleaching. This thermal treatment aims at enzyme inactivation, color fixation, gas removal, mainly oxygen from tissues, elimination of unpleasant odors and flavors, in addition to decreasing the superficial microbial load, to prevent its early deterioration and foodborne diseases [33].

The search for Salmonella ssp., was negative in the 35 samples tested, compared with studies by Almico et al. (2018) [24] on the assessment of microbiological and physical chemical of açaí pulps (Euterpe oleracea Mart.) and showed similar results with the study. In another study by Jones and Lemes (2014) [34] on microbiological analysis of açaí pulps marketed in a city in the south of Minas Gerais, this one presented similar results, as they were absent.

Regarding the comparison with the results of thermotolerant coliforms, they presented within the standards of Normative Instruction No. 60, of December 23, 2019 [35], which regulates the microbiological health standards for food and drinks, and establishes for fruit pulps with or without heat treatment, thermotolerant coliform count up to $10^{2} \mathrm{MPN} / \mathrm{g}$ as a microbiological standard. Compared with Almico et al. (2018) [24] on the evaluation of the microbiological, physicalchemical and chemical quality of açaí pulps (Euterpe oleracea Mart.) The results were similar with the present study. A study by Jones and Lemes (2014) [34] on microbiological analysis of açaí pulps, this one also presented similar results. 
According to de Jesus et al. (2019) [36] the effects of high hydrostatic pressure on microbial inactivation and extraction of bioactive compounds from the açaí pulp (Euterpe oleracea Mart.). In addition, obtained results of the absence of thermotolerant coliforms in the açai pulps, a comparative result with the present study. 
Table 2: Microbiological evaluation of açaí pulps in Igarapé-Miri, Pará.

\begin{tabular}{|c|c|c|c|c|c|c|}
\hline Type of açaí & Batch & $\begin{array}{c}\text { Trypanosoma cruzi } \\
(25 \mathrm{~g}) *\end{array}$ & $\begin{array}{c}\text { Salmonella ssp. } \\
(25 \mathrm{~g})\end{array}$ & $\begin{array}{c}\text { Thermotolerant } \\
\text { coliforms MPN/g* }\end{array}$ & $\begin{array}{c}\text { Filamentous Fungi } \\
\text { and Yeasts (UFC/g)* }\end{array}$ & $\begin{array}{l}\text { Aerobic mesophilic } \\
\text { bacteria (UFC/g)* }\end{array}$ \\
\hline \multirow{8}{*}{ Popular Açaí } & 1 & ND & Absence & $<3.0$ & $<100.0$ & $2.5 \times 10^{3}$ \\
\hline & 2 & ND & Absence & $<3.0$ & $<10.00$ & $7.0 \times 10^{2}$ \\
\hline & 3 & ND & Absence & $<3.0$ & $4.7 \times 10^{3}$ & $3.7 \times 10^{3}$ \\
\hline & 4 & ND & Absence & $<3.0$ & $4.4 \times 10^{3}$ & $1.0 \times 10^{2}$ \\
\hline & 5 & ND & Absence & $<3.0$ & $4.9 \times 10^{3}$ & $1.3 \times 10^{3}$ \\
\hline & 6 & ND & Absence & $<3.0$ & $6.9 \times 10^{2}$ & $8.1 \times 10^{3}$ \\
\hline & 7 & ND & Absence & $<3.0$ & $2.2 \times 10^{3}$ & $4.1 \times 10^{3}$ \\
\hline & 8 & ND & Absence & $<3.0$ & $4.7 \times 10^{3}$ & $5.2 \times 10^{2}$ \\
\hline \multirow{21}{*}{ Medium Açaí } & 1 & ND & Absence & $<3.0$ & $<10.00$ & $2.5 \times 10^{3}$ \\
\hline & 2 & ND & Absence & $<3.0$ & $<10.00$ & $2.5 \times 10^{2}$ \\
\hline & 3 & ND & Absence & $<3.0$ & $8.2 \times 10^{2}$ & $9.0 \times 10^{2}$ \\
\hline & 4 & ND & Absence & $<3.0$ & $<10.00$ & $1.0 \times 10^{2}$ \\
\hline & 5 & ND & Absence & $<3.0$ & $2.3 \times 10^{3}$ & $4.7 \times 10^{3}$ \\
\hline & 6 & ND & Absence & $<3.0$ & $3.7 \times 10^{3}$ & $3.8 \times 10^{3}$ \\
\hline & 7 & ND & Absence & $<3.0$ & $4.4 \times 10^{3}$ & $4.7 \times 10^{3}$ \\
\hline & 8 & ND & Absence & $<3.0$ & $4.2 \times 10^{3}$ & $3.8 \times 10^{3}$ \\
\hline & 9 & ND & Absence & $<3.0$ & $3.8 \times 10^{3}$ & $4.4 \times 10^{3}$ \\
\hline & 10 & ND & Absence & $<3.0$ & $4.0 \times 10^{3}$ & $3.3 \times 10^{3}$ \\
\hline & 11 & ND & Absence & $<3.0$ & $7.0 \times 10^{2}$ & $4.2 \times 10^{3}$ \\
\hline & 12 & ND & Absence & $<3.0$ & $1.0 \times 10^{2}$ & $3.9 \times 10^{3}$ \\
\hline & 13 & ND & Absence & $<3.0$ & $4.4 \times 10^{3}$ & $3.5 \times 10^{3}$ \\
\hline & 14 & ND & Absence & $<3.0$ & $6.3 \times 10^{2}$ & $5.0 \times 10^{2}$ \\
\hline & 15 & ND & Absence & $<3.0$ & $5.1 \times 10^{2}$ & $4.7 \times 10^{3}$ \\
\hline & 16 & ND & Absence & $<3.0$ & $1.0 \times 10^{2}$ & $3.9 \times 10^{3}$ \\
\hline & 17 & ND & Absence & $<3.0$ & $4.3 \times 10^{3}$ & $5.2 \times 10^{2}$ \\
\hline & 18 & ND & Absence & $<3.0$ & $4.4 \times 10^{3}$ & $4.0 \times 10^{2}$ \\
\hline & 19 & ND & Absence & $<3.0$ & $1.5 \times 10^{3}$ & $1.6 \times 10^{3}$ \\
\hline & 20 & ND & Absence & $<3.0$ & $4.5 \times 10^{3}$ & $2.7 \times 10^{3}$ \\
\hline & 21 & ND & Absence & $<3.0$ & $2.7 \times 10^{3}$ & $2.6 \times 10^{3}$ \\
\hline
\end{tabular}




\begin{tabular}{|c|c|c|c|c|c|c|}
\hline & 22 & ND & Absence & $<3.0$ & $2.7 \times 10^{3}$ & $6.0 \times 10^{2}$ \\
\hline & 23 & ND & Absence & $<3.0$ & $3.7 \times 10^{3}$ & $4.5 \times 10^{3}$ \\
\hline & 24 & ND & Absence & $<3.0$ & $4.2 \times 10^{3}$ & $4.7 \times 10^{2}$ \\
\hline \multirow{3}{*}{ Special Açaí } & 1 & ND & Absence & $<3.0$ & $<10.00$ & $4.7 \times 10^{2}$ \\
\hline & 2 & ND & Absence & $<3.0$ & $<10.00$ & $4.7 \times 10^{2}$ \\
\hline & 3 & ND & Absence & $<3.0$ & $3.6 \times 10^{3}$ & $4.1 \times 10^{3}$ \\
\hline Standard** & Max & ND & Absence & $10^{2}$ & $5 \times 10^{3}$ & - \\
\hline
\end{tabular}

ND: Not Detected. MPN: Most Probable Numbers. UFC: colony-forming units. *Average of samples. ** Normative Instruction No. 37, of October 1, 2018. 
Castro et al. (2016) [37] says that the presence of fungi in food above the maximum recommended by the legislation can compromise their food safety, since there are species of fungi that have a deteriorating or pathogenic action due to the production of myco toxins in the food. In a study on the microbiological quality assessment of frozen pasteurized açaí pulp (Euterpe oleracea Mart) type C.

Almico et al. (2018) [24] found similar results with the study, the samples did not show fungi and yeast contamination above that legislation allows, since the authors find results of molds that ranged between $4.99 \times 10^{2} \mathrm{CFU} / \mathrm{g}$, which are similar with the present study. In a study on the microbiological quality of industrialized acai.

The standard plate count of mesophilic aerobic bacteria is shown in Table 2, with the number of colonies obtained in each sample. Brazilian legislation does not establish limits for standard counts in mesophilic aerobic bacterial plaques [35, 38]. Franco and Landgraf (2005) [39] suggest that a count of up to $10^{6}$ is acceptable, which leads to classifying the samples suitable for consumption, since the results varied between $10^{2}$ to $8.1 \times 10^{3} \mathrm{CFU} / \mathrm{g}$ number of colonies.

\subsection{Heavy metals analysis}

The results of the heavy metals obtained in the present work are in accordance with the legal norms in force in the DRC $\mathrm{n}^{\circ}$ 42, of August 29, [40]; such results are important, as they indicate the reliability of the açaí pulp in the use of various preparations, excluding the risk of intoxication by these elements [41]. It is worth mentioning that the excess of these heavy metals can lead to disorders in the organism and, in extreme cases, even death [42]. Thus, the analysis of metals is extremely important for the quality of açaí pulps.

\subsection{Principal Component Analysis (PCA) and Cluster Analysis (HCA)}

Figure 1 shows the results of Principal Component Analysis (PCA) - To assess the quality of açaí pulps from different batches; we utilized parameters of $\mathrm{pH}$, total anthocyanins, total bacteria, and molds and yeasts. The parameters as Trypanossoma cruzi, thermotolerant coliforms and heavy metals) did not present numerical data to be considered in the analysis. 


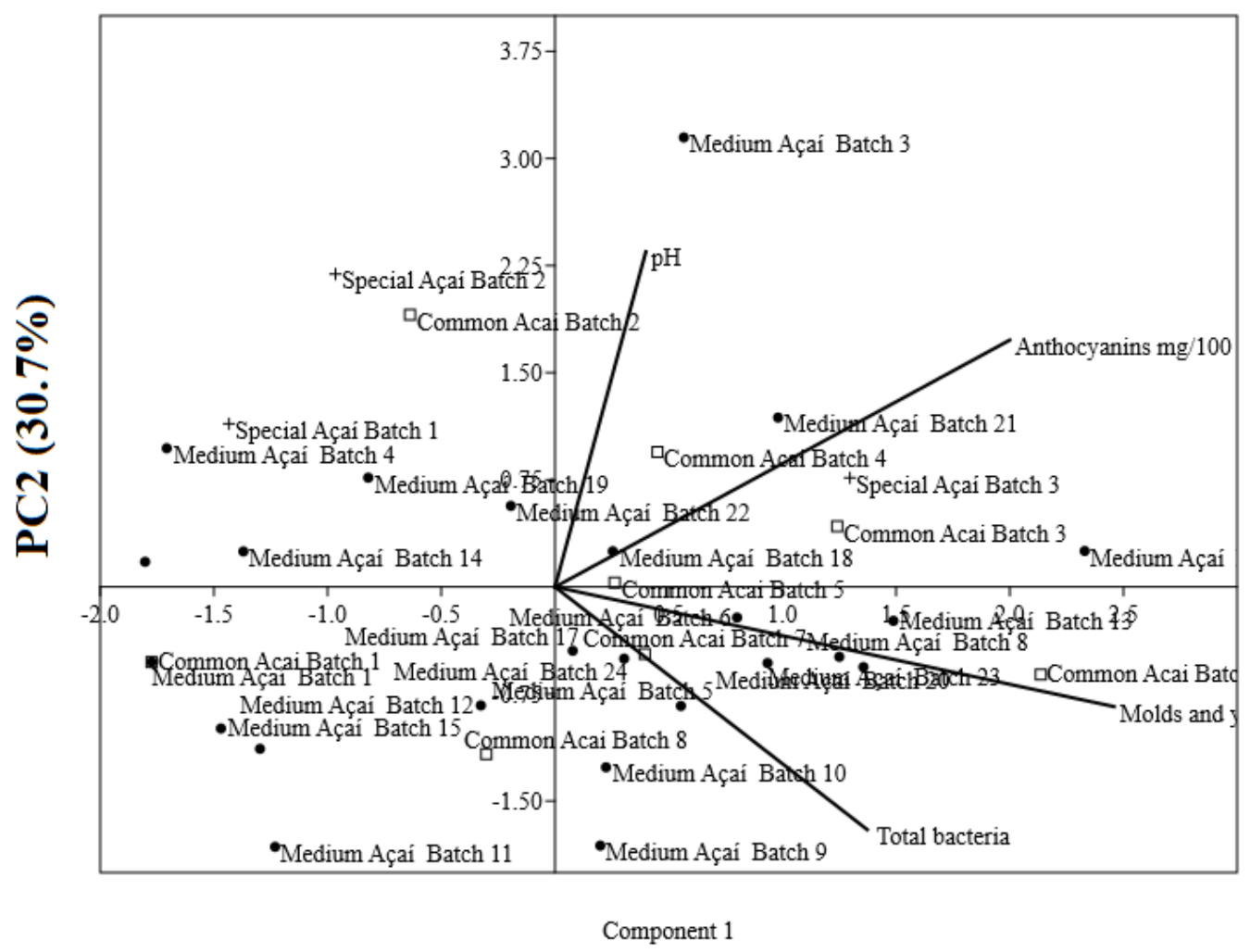

PC1 (35.3\%)

Figure 1: Graph of scores for the 35 lots of açaí pulp studied in Igarapé-Miri, Pará.

Based on the results obtained by the Principal Component Analysis (PCA) is possible to observe that $\mathrm{PC} 1$ and $\mathrm{PC} 2$ were responsible for $66.71 \%$ of the total variation in the different treatments (Figure 1), and according to Rencher (2003) [43] at least 70\% of the variation it must be explained by the first and second main component. PC1 was responsible for $35.3 \%$ and PC2 for $30.7 \%$. However, the present study did not achieve total variation only with the sum of $\mathrm{PC} 1$ and PC2, also influencing PC3 (not shown in the graph), which showed a value of $22.92 \%$, thus, the sum of PC1, PC2 and PC3 for the açaí samples correspond to $89.63 \%$ of the total variation of the evaluated quality parameters. The loading graph is shown in Figure 2 shows which parameters studied were most relevant for the distribution of samples in space. The parameters responsible for the definition and consequent separation of the referring group were total anthocyanins, total bacteria, molds and yeasts. 


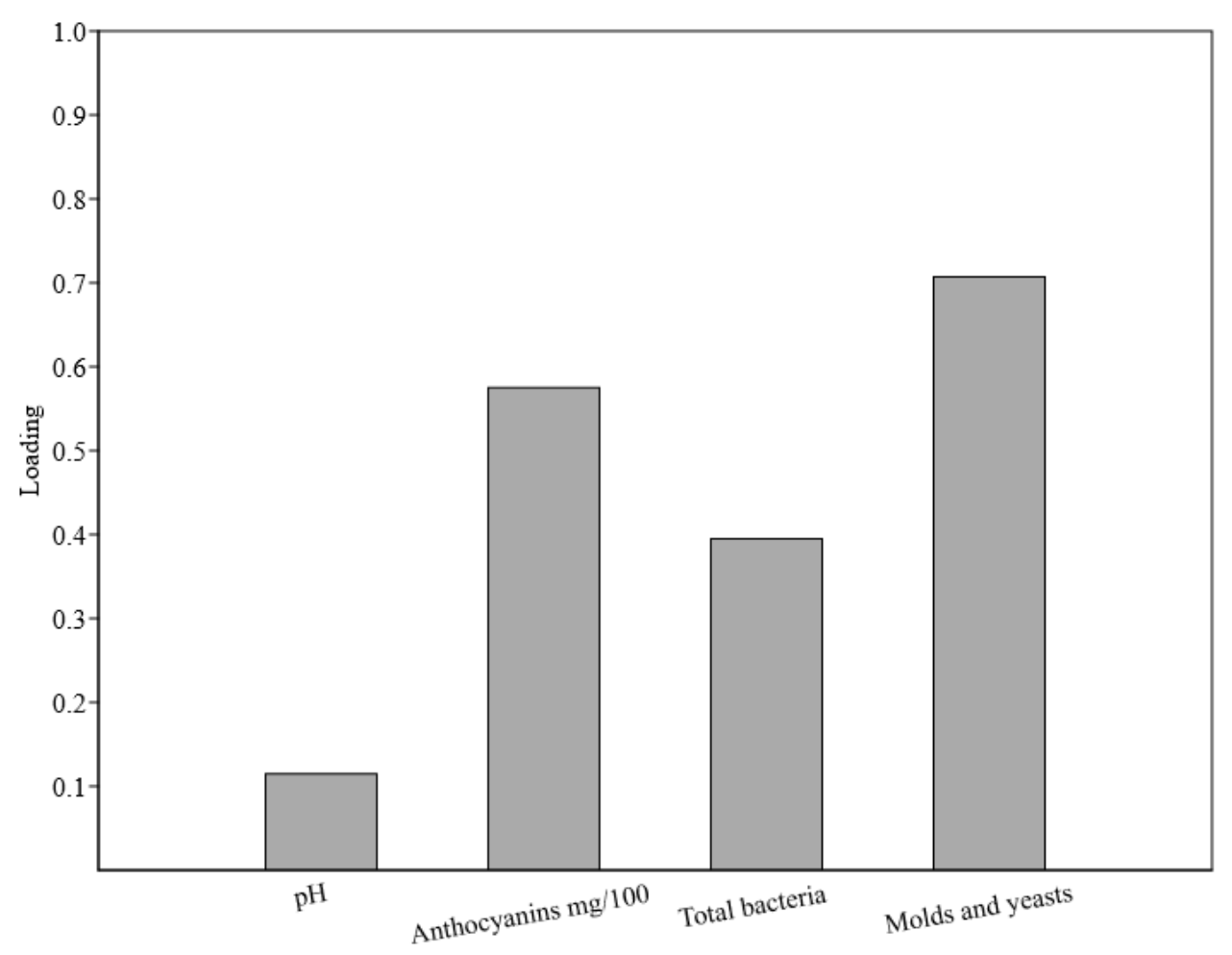

Figure 2: Loading graph based on the variables $p H$, total anthocyanins, total bacteria and molds and yeasts in Igarapé-Miri, Pará.

We can see in the Loading graph that the parameters of filamentous fungi and yeasts, anthocyanins and aerobic mesophilic bacteria were the ones that most tended in the variation, since any failure in relation to conservation and storage can compromise the quality of the product, leaving the product out of the adjustments of the legislation.

Figure 3 shows the graph of the dendrogram, where the UPGMA method (unweighted pair method with arithmetic mean) was used, being a simple method of agglomerated hierarchical grouping that determines the distance between groups of samples, which was the statistical hierarchical algorithm that best grouped the samples, according to the properties of the analytical data.

The dendrogram (Figure 3) shows that the principal component analysis (PCA), which uses the Euclidean distance defined as the hierarchical analysis (HCA) to represent the agglomeration done on a scale of 0 to 4 and shows similarities between the tests that are at the base of the dendrogram (considering the value up to 1 as significant for forming groups). Thus, this graph can confirm that there is formation of groups that present the greatest similarities between the trials, with three groups formed by the popular, medium and special açaí being formed, indicating that 28 of the 35 trials studied did not suffer great variations in relation to the evaluated parameters. Although 7 trials have suffered this influence, they were still within the parameters of the legislation as discussed in previous topics. In this way, we can correlate the influence of temperature and storage in relation to the variation of anthocyanin. Since studies by Albarici, Valeta and Pessoa (2007) [44] on the effect of temperature on the concentration of anthocyanin in açaí showed that when stored at temperatures of $0^{\circ} \mathrm{C}$ the degradation of anthocyanin occurs slowly, in relation to the other studied temperatures of $25^{\circ} \mathrm{C}$ and $40^{\circ} \mathrm{C}$. Because when stored at higher temperatures their degradation increases relatively, compromising the quality. At lower temperatures, there is a reduction in the movement of particles and a consequent decrease in intermolecular collision, and in freezing processes, metabolic reactions occur in a reduced way, but continue to occur during storage time [45]. 


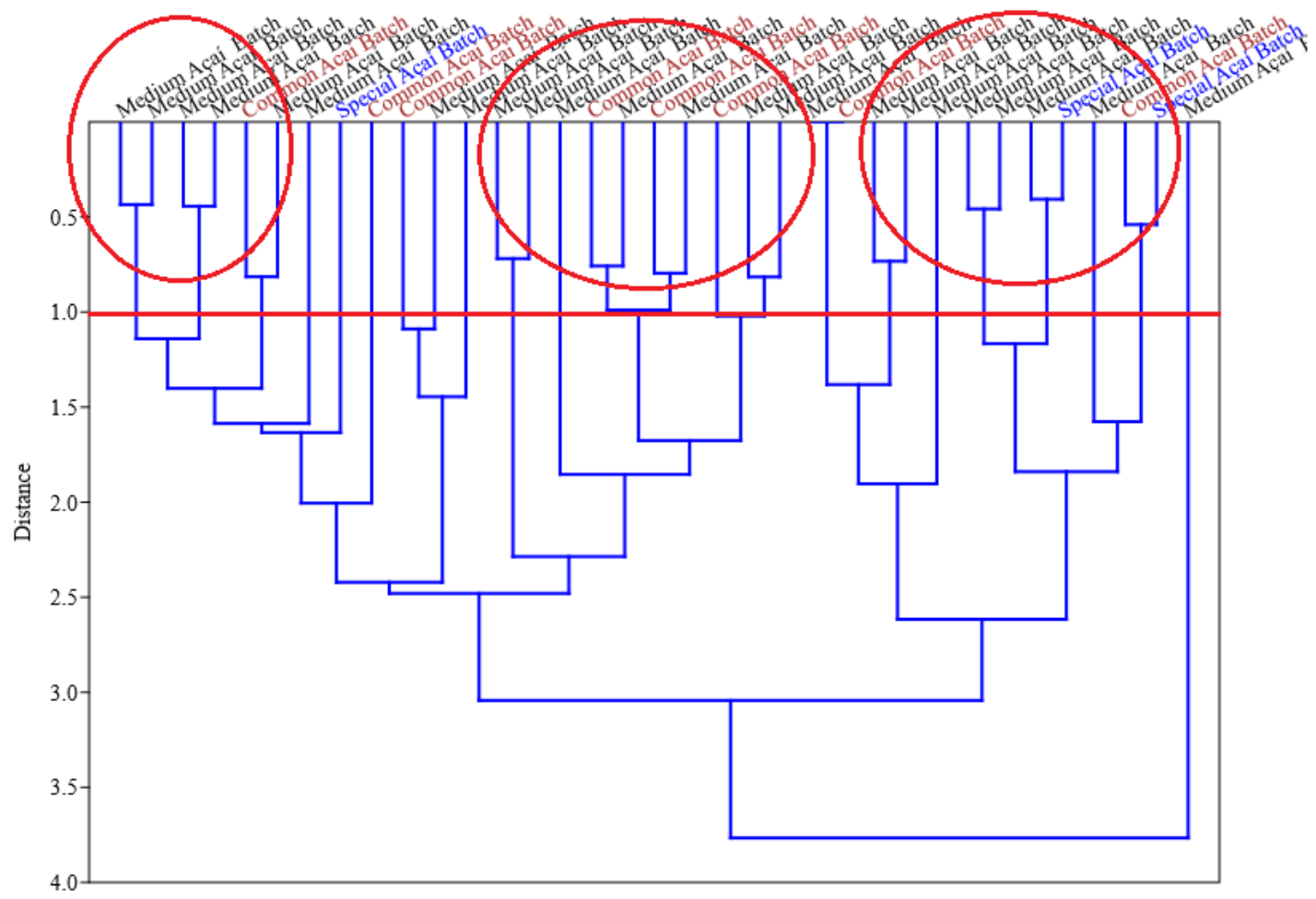

Figure 3: Dendrogram obtained from physical-chemical and microbiological analyzes of açai pulps in Igarapé-Miri, Pará.

Another factor that tends to influence the variation of filamentous fungi and yeasts is the relationship between food handling and storage, as a study on the determination of the microbiological quality of frozen açaí pulps sold in establishments in the city of Pouso Alegre, $8.3 \%$ of 36 samples analyzed. That interfered with the quality of the product. In addition, the issue of storage temperature had a great influence, because when stored for 48 hours at $30^{\circ} \mathrm{C}$, or at room temperature, these microorganisms increase two logarithmic cycles [46]. Therefore, temperature and handling are factors that are interconnected in the influence of the inhibition of molds and yeasts [47].

\section{CONCLUSION}

According to the microbiological results, it is concluded that the samples of açaí pulp analyzed are in accordance with the specifications required by the legislation, as they did not show contamination by thermotolerant coliforms, molds and yeasts, mesophilic aerobic bacteria and absence of salmonella ssp. and contamination by Trypanosoma cruzi. This result found is possibly justified by appropriate hygienic-sanitary conducts in food handling. Regarding heavy metals, they did not present a high concentration that causes food poisoning.

Regarding the results of the PCA, the parameters that most influenced were the analysis of anthocyanins, total bacteria and molds and yeasts, and of the 35 samples analyzed, 28 did not suffer variations for the evaluated parameters. Therefore, the excellent quality of the pulp is linked to factors that are established since harvesting, transport and pulping. In view of this, a quality product that follows the laws and normative instructions, minimizes the risks of contamination of consumers, in addition, the activity of açai generates jobs and income, from production to pulp processing, becoming essential for the development of the municipality of Igarapé-Miri/PA.

\section{ACKNOWLEDGMENTS}


The authors would like to acknowledge the State University of Pará - UEPA, the Federal Rural University of the Amazon - UFRA and the Monitoria laboratory, and the company Vale do açaí, Imp. and Exp. Indústria e Comercio- Bony Açaí.

\section{REFERENCES}

1. Poerner N, Rodrigues E, Palhano AL, Fiorentini AM. Avaliação das condições higiênico-sanitárias em serviços de alimentação. Rev Inst Adolfo. 2009;68(3):399-405.

2. Ebone M, Cavalli SB, Lopes SJ. Segurança e qualidade higiênico-sanitária em unidades produtoras de refeições comerciais. Rev Nutrição. 2011 Set/Out;24(5):725-734, doi: 10.1590/S141552732011000500006.

3. Berti RC, Santos DC. Importância do controle de qualidade na indústria alimentícia: prováveis medidas para evitar contaminação por resíduos de limpeza em bebida UHT. Atas de Ciências da Saúde. 2016 Maio;4(1):23-38.

4. Silva FS, Silva AFM, Sousa CL, Souza JN. Avaliação higiênico-sanitária dos estabelecimentos com o selo "Açaí Bom" da Vigilância Sanitária. Braz J Food Res. 2017 out/dez;8(4):157-169, doi:10.3895/rebrapa.v8n4.5024

5. Barcelos IB, Valiatti TB, Almeida FKV, Prazeres PFL, Calegari GM, Silva WMC, Sobral FOS, Romão NF. Qualidade microbiológica de polpas de açaí comercializadas no município de Ji-Paraná, Rondônia. Uniciências. 2017 mar;21(1):21-24, doi: 10.17921/1415-5141.2017v21n1p21-24.

6. Brasil. Ministério da Saúde - Secretaria de vigilância da saúde. Boletim Epidemiológico. 2019 Nov; 50 (36). Available from: https://www.saude.gov.br/images/pdf/2019/novembro/29/Boletimepidemiologico-SVS-36-interativo.pdf.

7. Mozart L. Secretaria de saúde do estado do Pará. Sespa intensifica monitoramento e treinamento para combater a doença de chagas [Internet]. 2019 Sep 12 [accessed 2020 May 5]. Available from: http://www.saude.pa.gov.br/sespa-intensifica-monitoramento-e-treinamento-para-combater-a-doencade-chagas/.

8. Silva B, Amorim TS. A produção, venda e renda do açaí: um estudo no município de Igarapé-Miri/PA (GT 18 - Agroecologia, economia(s) solidárias e mercados camponeses). In: Proceedings of the VIII Simpósio Internacional de Geografia Agrária (SINGA) e IX Simpósio Nacional de Geografia Agrária; 2017 Nov 1-5; Curituba, PR. [place unknown]: [publisher unknown]; 2017.

9. Sedap. Secretaria de Desenvolvimento Agropecuário de Pesca. Fronteiras se abrem para o açaí paraense em programa de industrialização [Internet]. 2018 Apr 24. [accessed 2020 Apr 12]. Available from: http://www.sedap.pa.gov.br/artigos/fronteiras-se-abrem-para-o-a\%C3\%A7a\%C3\%AD-paraense-emprograma-de-industrializa\%C3\%A7\% $3 \% \mathrm{~A} 30$

10. Instituto Adolfo Lutz. Métodos físico-químicos para análise de alimentos. 2 ed. São Paulo: Instituto Adolfo Lutz; 1976.

11. Giusti MM, Wrolstad RE. Anthocyanins: Characterization and measurement with UV visible spectroscopy. Current protocols in food analytical chemistry. 2001 Apr;00(1):F1.2.1-F.1.2.13, doi: 10.1002/0471142913.faf0102s00

12. Apha. American Public Health Association. Committee on microbiological metods for foods. Compendium of methods for the microbiological examination of foods. 4 ed. Washington: APHA, 2001. 676p.

13. ISO. International Organization for Standardization. Microbiology of food and animal feeding stuffs Horizontal method for the enumeration of yeasts and moulds. Part 1: Colony count technique in products with water activity greater than 0.95 . [place unknown]: [publisher unknown]; 2008 Jul. 8 p. Report No.: ISO 21527-1:2008.

14. ISO. International Organization for Standardization. Microbiology of food and animal feeding stuffs Horizontal method for the detection of Salmonella spp. - Amendment 1: Annex D: Detection of Salmonella spp. in animal faeces and in environmental samples from the primary production stage. [place unknown]: [publisher unknown]; 2007 Jul. 9 p. Report No.: ISO 6579:2002/AMD 1:2007.

15. ISO. International Organization for Standardization. Microbiology of food and animal feeding stuffs Polymerase chain reaction (PCR) for the detection of food-borne pathogens - Requirements for sample preparation for qualitative detection. [place unknown]: [publisher unknown]; 2006 Apr. 7 p. Report No.: 20837:2006(E).

16. EPA. SW-846 Test Method 7000B: Flame Atomic Absorption Spectrophotometry, Revision 2. [place unknown]: [publisher unknown]; 2007 Feb. 23 p. Report No.: SW-846. 
17. Apha. American Public Health Association. SM 3111B. Standard Methods for Examination of Water and WasteWater. Washington DC : Analytical Public Health Association, Centennial Edition; 2005. Report No.: SM 3111B.

18. EPA. US Environmetal Protection Agency. Method 6010c: Inductively coupled plasma-atomic emission spectrometry (ICP-AES), Revision 3. . [place unknown]: [publisher unknown]; 2000 Nov. 34 p. Report No.: EPA-RCA: 3010 C.

19. EPA. Method 1631, Revision E: Mercury in Water by Oxidation, Purgue and Trap, and Cold Vapor Atomic Fluorescence Spectrometry. [place unknown]: [publisher unknown]; 2002 Aug. 38 p. Report No.: EPA-EAD: 1631.

20. Hammer O, David ATH, Paul DR. PAST: Paleontological statistics software package for education and data analysis. Palaeontol Electron. 2001 Maio-Jun;4(1):1-9.

21. Brasil. Ministério da Agricultura e do Abastecimento. Portaria no 94, de 30 de Agosto de 2016. Anexo que estabelece a complementação dos padrões de identidade e qualidade de polpa de fruta. Diário Oficial da União, no 169, Seção 1, p. 2 (Sep 01, 2016).

22. Brasil. Ministério da Agricultura e do Abastecimento. Instrução Normativa, $n^{\circ} 37$, de 1 de outubro de 2018. Parâmetros analíticos e quesitos complementares aos padrões de identidade e de suco de fruta. Diário Oficial da União, no 194, Seção 1, p. 23 (Oct 8, 2018).

23. Alquino CM, Moreira LF, Mendes AHL, Santos SML, Monte ALS. Avaliação físico-química e microbiológica de açaí (Euterpe oleracea) congelado pronto para o consumo comercializado em Limoeiro do Norte-Ceará. Bio Amaz. 2019 Jan-Mar;9(3):35-40, doi:or/10.18561/21795746/biotaamazonia.v9n3p35-40.

24. Almico JD, Ferreira IM, Ramos GD, e Silva AMO, de Carvalho MG. Avaliação da qualidade microbiológica, físico-química e química de polpas de açaí (Euterpe oleracea Mart) pasteurizadas congeladas comercializadas em Aracaju-SE. Rev BrasHigSan Anim. 2018 Abr-Jun;12(2):156-168, doi:org/10.5935/1981.20180015.

25. Gava AJ, da Silva CAB, Frias JRG. Tecnologia de alimentos. São Paulo: NBL Editora; 2009. 511 p.

26. Jay JM, Loessner MJ, Golden DA. Modern food Microbiology. 7 ed. New York: Springer; 2005. 790 p.

27. Rogez H, Pompeu DR, Akwie SNT, Larondelle, Y. Sigmoidal kinetics of anthocyanin accumulation during fruit ripening: a comparison between açai fruits (Euterpe oleracea) and other anthocyanin-rich fruits. J Food Compos Anal. 2011 Set;24(6):796-800, doi.10.1016/j.jfca.2011.03.015

28. da Silva AKN, Beckman JC, Rodrigues AM da C, da Silva LHM. Avaliação da composição nutricional e capacidade antioxidante de compostos bioativos da polpa de açaí. Rev Bras Tecnol Agroind. 2017 JanJun;11(1):2205-2216, doi 10.3895/rbta.v11n1.2829

29. Gu KD, Wang CK., Hu DG, Hao YJ. How do anthocyanins paint our horticultural products? Sci Horticult. 2019 Abr;249:257-262, doi.org/10.1016/j.scienta.2019.01.034.

30. de Mattos EC, Marciano MAM, Ferreira ARS, Chioccola VLP. Determinação da viabilidade de Trypanosoma cruzi em polpa de açaí e caldo de cana de açúcar experimentalmente contaminados. BEPA. 2019;16(183):15-23.

31. Passos LAC, Guaraldo AMA, Barbosa RL, Dias VL, Pereira KS, Schmidt FL, Franco RMB, Alves, DP. Sobrevivência e infectividade do Trypanosoma cruzi na polpa de açaí: estudo in vitro e in vivo. Epidemiol Serv Saúde. 2012 Abr-Jan; 21(2):223-232, doi: 10.5123/S1679-49742012000200005.

32. Anvisa. Agência Nacional de Vigilância Sanitária. Informe Técnico n³5, de 19 de junho de 2008. Gerenciamento do Risco Sanitário na Transmissão de Doença de Chagas Aguda por Alimentos.

33. Vasconcelos MAS, Melo-Filho AB. Técnico em Alimentos. Conservação de Alimentos. Recife: EDUFRPE; 2010. 130p.

34. Jones LC, Lemes RML. Análise microbiológica de polpas de açaí comercializadas em uma cidade do sul de Minas Gerais. Rev Univ Vale Rio Verde. 2014 Dez;12(2):601-608, doi:10.5892/ruvrd.v12i2.1509.

35. Brasil. Agência Nacional de Vigilância Sanitária. Instrução normativa n ${ }^{\circ}$. 60, de 23 de dezembro de 2019. Estabelece as listas de padrões microbiológicos para alimentos. Diário Oficial da União, nº 249, Seção 1 (Dez 26, 2019).

36. de Jesus ALT, Cristianini M, dos Santos NM, Maróstica Júnior MR. Effects of high hydrostatic pressure on the microbial inactivationand extraction of bioactive compounds from açaí (Euterpe oleracea Martius) pulp. Food Res Int. 2019 Nov;130:1-49, doi: 10.1016/j.foodres.2019.108856.

37. Castro RW, Borges GSC, Gonzaga LV, Ribeiro DHB. Qualidade do preparado para bebida obtido a partir de polpa de juçara submetida ao tratamento térmico. Braz J Food Tec. 2016 Maio;19:1981-6723, doi:10.1590/1981-6723.0815.

38. Brasil. Ministério da Agricultura e do Abastecimento. Portaria nº. 451, de 19 de setembro de 1997. Regulamento técnico princípios gerais para o estabelecimento de critérios e padrões microbiológicos para alimentos. Diário Oficial da União, Secão 1 (Sep 22, 1997)

39. Franco BDGM, Landgraf M. Microbiologia dos Alimentos. São Paulo: Atheneu Editora, 2005. 196 p. 
40. Brasil. Agência Nacional de Vigilância Sanitária. Resolução RDC 42 de 29 de agosto de 2013. Regulamento Técnico Mercosul sobre Limites Máximos de Contaminantes Inorgânicos em Alimentos.

41. Menezes SEM, Torres AT, Srur AUS. Valor nutricional da polpa de açaí (Euterpe oleracea Mart) liofilizada. Acta Amaz. 2008 Mar;38(2):311-316, doi:10.1590/S0044-59672008000200014.

42. Virga RHP, Geraldo LP, Santos FH. Avaliação de contaminação por metais pesados em amostras de siris azuis. Ciênc Tecnol Aliment, 2007 Out-Dez;27(4):779-785, doi:10.1590/S0101-20612007000400017.

43. Rencher AC. Methods of multivariate analysis. E-book. United States of America: John Wiley \& Sons; 2003. $738 \mathrm{p}$.

44. Albarici TR, Valeta A C, Pessoa JDC. Efeito da Temperatura nas Antocianinas do Açaí. Comunicado Técnico, Embrapa. 2007 Out;1517-4786.

45. Faria M, Oliveira LBD, Costa FEC. Determinação da qualidade microbiológica de polpas de açaí congeladas comercializadas na cidade de Pouso Alegre - MG. Alim Nutr. 2012 Abr-Jun;23(2): 243-249.

46. Gonçalves RL. Avaliação da qualidade microbiológica do açaí comercializado no município de BarretosSP [trabalho de conclusão de curso]. Barretos [SP]: IFSP; 2017. 30 p.

47. Silva N, Junqueira VCA, Silveira NFA, Taniwaki MH, Santos RFS, Gomes RAR. Manual de Métodos de Análise Microbiológica de Alimentos. 4.ed.- São Paulo: Livraria Varela; 2010. 614 p. 